\title{
Effect of copper and zinc on blood and milk parameters and performance of dairy cows
}

\author{
Z.-B. Yang'1, W.-R. Yang, S.-Z. Jiang, G.G. Zhang, Z.Y. Li and H. Zhao \\ Department of Animal Nutrition, Shandong Agricultural University \\ Daizong Road No.61,Taian, 271018 Shandong, P.R. China
}

\begin{abstract}
Thirty fives Holstein cows were chosen to study the blood biochemical indicators with a singlefactor test design in three copper levels $(21.5,31.5$ and $41.5 \mathrm{mg} / \mathrm{kg})$ and three zinc levels $(50.15$, 90.15 and $130.15 \mathrm{mg} / \mathrm{kg}$ ). The results showed that the supplement of $20 \mathrm{mg}$ of $\mathrm{Cu} / \mathrm{kg} \mathrm{DM}$ and above $40 \mathrm{mg}$ of $\mathrm{Cu} / \mathrm{kg} \mathrm{DM}$ may increase $\mathrm{Cu}-\mathrm{Zn}$-superoxide dismutase ( $\mathrm{Cu}-\mathrm{Zn}-\mathrm{SOD})$ in milk ( $\mathrm{P}<0.05)$, but did not increase milk yield and improve chemical composition ( $\mathrm{P}>0.05)$. Zinc concentration in milk could be higher as supplemented $80 \mathrm{mg}$ of $\mathrm{Zn} / \mathrm{kg} \mathrm{DM}(\mathrm{P}<0.05)$. The concentration of copper, serum ceruloplasmin, haemoglobin and the activity of $\mathrm{Cu}-\mathrm{Zn}$-SOD in blood may be increased $(\mathrm{P}<0.01)$ by $37,60,5.1$ and $5.9 \%$, respectively, as the supplement of dietary copper was above $31.5 \mathrm{mg} / \mathrm{kg}$.
\end{abstract}

KEY WORDS: copper, zinc, performance, blood, milk, cows

\section{INTRODUCTION}

Zinc is essential for the activities of more than 100 enzymes in the body. It is an essential component of the antioxidant enzyme, $\mathrm{Cu}-\mathrm{Zn}$ superoxide dismutase (Bitman et al., 1991). Copper is contained in a number of enzymes and proteins, and its role has been defined for many physiological functions related mostly to a catalytic agent in the active sites of cuproenzymes (McDowell, 1992). Recent studies have also shown that cows supplemented with copper at $20 \mathrm{ppm}$ in feed/day in addition to basal diet had more uninfected quarters compared to nonsupplemented cows (Singh and Bansal, 2001). The purpose of our research was to study the contribution of high level copper and zinc in dietary to the performance and biochemical parameters of dairy cows.

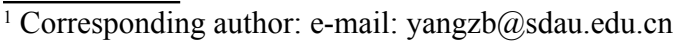




\section{MATERIAL AND METHODS}

\section{Animals and diets}

Thirty fives multiparous Holstein cows were housed individualy. Based on individual feed intake data, a 2-week pre-trial period was sufficient for cows to adjust to the new diet. Before the initiation of the experiment, groups with five cows similar in parity, dry matter intake (DMI) and milk yield were assigned randomly to one of the following seven treatments: 1. control (no supplemental $\mathrm{Cu}, \mathrm{Zn}$, the levels of copper and zinc were 21.5 and $50.15 \mathrm{mg} / \mathrm{kg}$ in diet respectively), $2.10 \mathrm{mg}$ of $\mathrm{Cu} / \mathrm{kg} \mathrm{DM}$ from $\mathrm{Cu}$ sulphate (the levels of copper and zinc were 31.5 and 50.15 $\mathrm{mg} / \mathrm{kg}$ in diet, respectively), 3. $20 \mathrm{mg}$ of $\mathrm{Cu} / \mathrm{kg} \mathrm{DM}$ from $\mathrm{Cu}$ sulphate (the levels of copper and zinc were 41.5 and $50.15 \mathrm{mg} / \mathrm{kg}$ in diet, respectively), $4.40 \mathrm{mg}$ of $\mathrm{Zn} / \mathrm{kg} \mathrm{DM}$ from $\mathrm{Zn}$ sulphate (the levels of copper and zinc were 21.5 and $90.15 \mathrm{mg} / \mathrm{kg}$ in diet, respectively), and $5.80 \mathrm{mg}$ of $\mathrm{Zn} / \mathrm{kg}$ DM from $\mathrm{Zn}$ sulphate (the levels of copper and zinc were 21.5 and $130.15 \mathrm{mg} / \mathrm{kg}$ in diet, respectively). The diets were formulated containing, \%: CP 13.25, Ca 0.50, P 0.30, and other nutrients meeting or exceeding NRC (2001) recommendations with the exception of $\mathrm{Cu}$ and $\mathrm{Zn}$, using maize silage (13.7\%), peanut stalk (17.0\%), sweet potato vine $(17.0 \%)$ and supplement $(52.3 \%)$.

\section{Sample collection and analysis}

Blood samples were taken at the end of the experiment. Feed was removed for $1 \mathrm{~h}$ before the initiation of blood collection. A $15 \mathrm{ml}$ sample of blood was collected by coccygeal venipuncture into heparinized evacuated tubes. Samples were placed with ice and then transported to the laboratory. Plasma was separated by centrifugation $\left(3000 \mathrm{~g}\right.$ ) and then stored at the temperature $-20^{\circ} \mathrm{C}$ before analysed.

The cows were milked twice daily at 07.00 and 16.00. Milk yield was recorded, and milk samples were collected at the end of the experiment and analysed the fat, protein, lactose (UL20AC, Ultrasun Technologies CO., Ltd.), and milk copper zinc superoxide dismutase $(\mathrm{Cu}-\mathrm{Zn}-\mathrm{SOD})$ activity. Plasma $\mathrm{Cu}$ and $\mathrm{Zn}$ concentrations were measured after the samples were thawed at room temperature for 3 to $4 \mathrm{~h}$. For $\mathrm{Cu}$ analysis, $1 \mathrm{ml}$ of a 10\% (w/v) trichloroacetic acid solution was added to $1 \mathrm{ml}$ of plasma or standard and then vortexed vigorously for $20 \mathrm{sec}$. To aid in precipitation, the sample was placed in a $-20^{\circ} \mathrm{C}$ freezer for $30 \mathrm{~min}$, and then centrifuged at $1,200 \mathrm{~g}$ for $10 \mathrm{~min}$ at room temperature. The supernatant was removed and diluted in deionized water to the concentrations that fit within a linear range of a standard curve generated by linear regression of known concentrations. Plasma $\mathrm{Cu}$ concentrations were read at $324.7 \mathrm{~nm}$ using a flame atomic absorption 
spectrophotometer (HITACHI 180-80). Plasma Zn concentrations were analysed in a similar manner as described above; they were determined at $213.9 \mathrm{~nm}$.

Statistical analysis

Datas were analysed by ANOVA using the statistical program SAS.

\section{RESULTS}

Dry matter intake averaged $26.6 \mathrm{~kg}$ across all treatments and was not affected $(\mathrm{P}>0.05)$ by the inclusion of supplemental copper and zinc (Table 1).

Table 1. Effect of supplemental different levels of copper and zinc on production, chemical composition and copper-zinc-superoxide dismutase activity of milk in Holstein cows

\begin{tabular}{|c|c|c|c|c|c|c|c|c|}
\hline \multirow[t]{2}{*}{ Item } & \multicolumn{3}{|c|}{$\begin{array}{c}\text { Supplemental } \mathrm{Cu} \\
\mathrm{mg} \mathrm{Cu} / \mathrm{kg} \mathrm{DM}\end{array}$} & \multirow[t]{2}{*}{ SEM } & \multicolumn{3}{|c|}{$\begin{array}{c}\text { Supplemental Zn } \\
\text { mg Zn /kg DM }\end{array}$} & \multirow[t]{2}{*}{ SEM } \\
\hline & 0 & 10 & 20 & & 0 & 40 & 80 & \\
\hline DMI, kg/d & 26.55 & 26.73 & 26.60 & 0.21 & 26.70 & 26.67 & 26.57 & 0.26 \\
\hline Milk yield, $\mathrm{kg} / \mathrm{d}$ & $19.03^{\mathrm{a}}$ & $19.93^{\mathrm{a}}$ & $19.60^{\mathrm{a}}$ & 1.88 & $19.03^{\mathrm{a}}$ & $19.92^{\mathrm{a}}$ & $19.87^{\mathrm{a}}$ & 2.77 \\
\hline \multicolumn{9}{|l|}{ Milk composition } \\
\hline fat, $\%$ & $3.02^{\mathrm{a}}$ & $3.05^{\mathrm{a}}$ & $2.98^{\mathrm{a}}$ & 0.09 & $3.02^{\mathrm{a}}$ & $3.01^{\mathrm{a}}$ & $3.07^{\mathrm{a}}$ & 0.70 \\
\hline protein, $\%$ & $3.04^{\mathrm{a}}$ & $3.01^{\mathrm{a}}$ & $3.06^{\mathrm{a}}$ & 0.06 & $3.04^{\mathrm{a}}$ & $3.12^{\mathrm{a}}$ & $3.05^{\mathrm{a}}$ & 0.21 \\
\hline lactose, $\%$ & $4.77^{\mathrm{a}}$ & $4.72^{\mathrm{a}}$ & $4.75^{\mathrm{a}}$ & 0.12 & $4.77^{\mathrm{a}}$ & $4.87^{\mathrm{a}}$ & $4.82^{\mathrm{a}}$ & 0.13 \\
\hline copper, mg/l & $0.25^{\mathrm{a}}$ & $0.30^{\mathrm{a}}$ & $0.33^{\mathrm{a}}$ & 0.06 & $0.25^{\mathrm{a}}$ & $0.24^{\mathrm{a}}$ & $0.26^{\mathrm{a}}$ & 0.02 \\
\hline zinc, $\mathrm{mg} / \mathrm{l}$ & $5.66^{\mathrm{a}}$ & $5.65^{\mathrm{a}}$ & $5.63^{\mathrm{a}}$ & 0.81 & $5.66^{\mathrm{a}}$ & $5.91^{\mathrm{a}}$ & $6.12^{\mathrm{b}}$ & 0.84 \\
\hline iron, mg/l & $4.30^{\mathrm{a}}$ & $4.82^{\mathrm{a}}$ & $4.42^{\mathrm{a}}$ & 0.19 & $4.30^{\mathrm{a}}$ & $4.32^{\mathrm{a}}$ & $4.23^{\mathrm{a}}$ & 0.19 \\
\hline $\mathrm{Cu}-\mathrm{Zn}-\mathrm{SOD}, \mathrm{U} / \mathrm{ml}$ & $47.31^{\mathrm{a}}$ & $48.25^{\mathrm{a}}$ & $54.11^{\mathrm{b}}$ & 4.24 & $47.31^{\mathrm{a}}$ & $66.52^{\mathrm{b}}$ & $84.14^{\mathrm{c}}$ & 4.58 \\
\hline
\end{tabular}

Supplemental copper and zinc have no effect on average daily milk yield and milk composition. But Cu-Zn-SOD in supplemental $20 \mathrm{mg}$ of $\mathrm{Cu} / \mathrm{kg}$ DM treatment was higher than that of other two treatments $(\mathrm{P}<0.05)$, and was greater from cows supplemented with high relative to low dietary zinc levels $(\mathrm{P}<0.05)$. Milk zinc concentration in supplemental $80 \mathrm{mg}$ of $\mathrm{Zn} / \mathrm{kg}$ DM treatment was higher than that of other two treatments $(\mathrm{P}<0.05)$.

The concentration of copper, serum ceruloplasmin, and the activity of $\mathrm{Cu}-\mathrm{Zn}$ SOD in blood were raised up $(\mathrm{P}<0.01)$ by 37,60 and $5.9 \%$, respectively (Table 2$)$, as the copper level was raised from 21.5 to $31.5 \mathrm{mg} / \mathrm{kg}$, but the concentration of zinc in blood was not affected $(\mathrm{P}>0.05)$ by the inclusion of supplemental copper and zinc. In the same certain level of zinc there was a significant increase (by 5.1\%) in the concentration of haemoglobin in blood $(\mathrm{P}<0.01)$ when the copper level in diet was raised from 21.5 to $41.5 \mathrm{mg} / \mathrm{kg}$. In the same certain level of copper, there was no 
effect $(\mathrm{P}>0.05)$ on concentration of copper, zinc, serum ceruloplasmin, haemoglobin and the activity of $\mathrm{Cu}-\mathrm{Zn}-\mathrm{SOD}$ in blood as the zinc level was raised up.

Table 2. Comparison of blood biochemistry indices with different diet copper and zinc levels

\begin{tabular}{|c|c|c|c|c|c|c|c|c|}
\hline \multirow[t]{2}{*}{ Item } & \multicolumn{3}{|c|}{$\begin{array}{c}\text { Supplemental } \mathrm{Cu} \\
\mathrm{mg} \mathrm{Cu} / \mathrm{kg} \mathrm{DM}\end{array}$} & \multirow[t]{2}{*}{ SEM } & \multicolumn{3}{|c|}{$\begin{array}{c}\text { Supplemental Zn } \\
\mathrm{mg} \mathrm{Zn} \mathrm{/kg} \mathrm{DM}\end{array}$} & \multirow[t]{2}{*}{ SEM } \\
\hline & 0 & 10 & 20 & & 0 & 40 & 80 & \\
\hline Copper in blood, ug/ml & $0.97^{\mathrm{a}}$ & $1.33^{\mathrm{b}}$ & $1.53^{\mathrm{b}}$ & 0.15 & $0.97^{\mathrm{a}}$ & $0.94^{\mathrm{a}}$ & $0.93^{\mathrm{a}}$ & 0.07 \\
\hline Zinc in blood, ug/ml & $5.79^{\mathrm{a}}$ & $5.69^{\mathrm{a}}$ & $5.39^{\mathrm{a}}$ & 0.04 & $5.79^{\mathrm{a}}$ & $5.73^{\mathrm{a}}$ & $5.61^{\mathrm{a}}$ & 0.59 \\
\hline $\mathrm{Cu}-\mathrm{Zn}-\mathrm{SOD}, \mathrm{U} / \mathrm{ml}$ & $119.95^{\mathrm{a}}$ & $127.05^{\mathrm{b}}$ & $128.87^{b}$ & 2.88 & $119.95^{\mathrm{a}}$ & $114.75^{\mathrm{a}}$ & $108.46^{\mathrm{a}}$ & 6.52 \\
\hline Ceruloplasmin, U/1 & $9.67^{\mathrm{a}}$ & $15.48^{\mathrm{b}}$ & $16.19^{b}$ & 0.1 & $9.67^{\mathrm{a}}$ & $9.36^{\mathrm{a}}$ & $9.28^{\mathrm{a}}$ & 1.33 \\
\hline Haemoglobin, $\mathrm{g} / 1$ & $97.5^{\mathrm{a}}$ & $100^{\mathrm{ab}}$ & $102.5^{\mathrm{b}}$ & 1.62 & $97.5^{\mathrm{a}}$ & $98^{\mathrm{a}}$ & $101.5^{\mathrm{a}}$ & 2.82 \\
\hline
\end{tabular}

\section{DISCUSSION}

The addition of 10 and $20 \mathrm{mg}$ of $\mathrm{Cu} / \mathrm{kg} \mathrm{DM}$, or 40 and $80 \mathrm{mg}$ of $\mathrm{Zn} / \mathrm{kg} \mathrm{DM}$ to the control diet did not improve cows performance or change milk chemical composition. This suggests that the control diet was adequate in $\mathrm{Cu}$ and $\mathrm{Zn}$ to meet requirements of producing cows. $\mathrm{Cu}-\mathrm{Zn}$-SOD in supplemental $20 \mathrm{mg}$ of $\mathrm{Cu} / \mathrm{kg} \mathrm{DM}$ and above $40 \mathrm{mg}$ of $\mathrm{Zn} / \mathrm{kg}$ DM was higher than that of other treatments $(\mathrm{P}<0.05)$. This suggests that $41.5 \mathrm{mg}$ of dietary copper and above $90.15 \mathrm{mg}$ of dietary zinc could improve the activity of superoxide dismutase in milk. Holstein $\times$ Simmental calves fed a control diet ( $35 \mathrm{mg}$ of $\mathrm{Zn} / \mathrm{kg}$ ) or the control supplemented with $10 \mathrm{mg}$ of $\mathrm{Zn} / \mathrm{kg}$ had similar $\mathrm{Zn}$ concentration in muscle, liver, bone, and hair at the end of a 284-day study (Kessler et al., 2003). With the exception of rib cartilage and rumen, tissue $\mathrm{Zn}$ concentration also were similar in lactating dairy cows fed diets containing 16.6 or $39.5 \mathrm{mg}$ of $\mathrm{Zn} / \mathrm{kg}$ for 42 days (Neathery et al., 1973). Tissue $\mathrm{Zn}$ concentration are well controlled by homeostatic changes in absorption and faecal endogenous excretion of $\mathrm{Zn}$. Supplementation with high concentration $(500 \mathrm{mg} /$ $\mathrm{kg}$ ) of $\mathrm{Zn}$ in the present study resulted in elevated concentration of $\mathrm{Zn}$ in plasma, liver, kidney, and bone shaft (Kincaid et al., 1997).

The concentration of copper, serum ceruloplasmin, haemoglobin and the activity of $\mathrm{Cu}-\mathrm{Zn}-\mathrm{SOD}$ in blood were raised up $(\mathrm{P}<0.01)$, as the copper level was raised up, but there were no effects $(\mathrm{P}>0.05)$, as the zinc level was raised up. The concentration of zinc in blood was not affected $(\mathrm{P}>0.05)$ by the inclusion of supplemental copper or zinc. This indicates that high level of zinc in diet blocked the absorption of copper in diet. The concentration of copper in dairy cow blood was decreased as the zinc in the diet reached $2000 \mathrm{mg} / \mathrm{kg}$. While the zinc level is $1000 \mathrm{mg} / \mathrm{kg}$, there was no significant affect to the concentration of copper in cow blood (Miller et al., 1989). Copper and zinc are known components of SOD, and $\mathrm{Cu}$ seems to regulate the enzyme's activity (Paynter et al., 1979). 


\section{CONCLUSIONS}

Supplement of dietary copper and zinc may increase $\mathrm{Cu}-\mathrm{Zn}$-superoxide dismutase in milk, but did not increase milk yield and improve chemical compositions. The concentration of copper, serum ceruloplasmin, haemoglobin and the activity of $\mathrm{Cu}-\mathrm{Zn}-\mathrm{SOD}$ in blood may be increased by the supplement of dietary copper, not the dietary zinc.

\section{REFERENCES}

Bitman J., Wood D.L., Bright S.A., Miller R.H., Capuco A.V., Roche A., Pankey J.W., 1991. Lipid composition of teat canal keratin collected before and after milking from Holstein and Jersey cows. J. Dairy Sci. 74, 414-420

Kessler J., Morel I., Dufey F.A., Gutzwiller A., Stern A., Geyes H., 2003. Effect of organic zinc sources on performance, zinc status, and carcass, meat, and claw quality in fattening bulls. Livest. Prod. Sci. 81, 171-171

Kincaid R.L., Chew B.P., Cronrath J.D., 1997. Zinc oxide and amino acids as sources of dietary zinc for calves: Effects on uptake and immunity. J. Dairy Sci. 80, 1381-1388

McDowell L.R., 1992. Copper and molybdenum. In: Minerals in Animal and Human Nutrition. Academic Press Inc., San Diego, CA, pp. 176-204

Miller W.J., Amos H.E., Gentry R.P., Blackmon D.M., Durrance R.M., Crowe C.T., Fielding A.S., Neathery M.W., 1989. Long-term feeding of high zine sulfate diets to lactating and gestating dairy cows. J. Dairy. Sci. 72, 1499-1508

Neathery N.W., Miller W.J., Blackmon D.M., Gentry R.P., Jones J.B., 1973. Absorption and tissue zinc content in lactating dairy cows as affected by low dietary zinc. J. Anim. Sci. 37, 848-852

Paynter D.I., Moir R.J., Underwood E.J., 1979. Changes in activity of the $\mathrm{Cu}-\mathrm{Zn}$ superoxide dismutase enzyme in tissues of the rat with changes in dietary copper. J. Nutr. 109, 1570-1576

Singh K.B., Bansal B.K., 2001. Control of mastitis: a nutritional approach. In: Proceedings of the Round Table on Mastitis, VIII Annual Conference of Indian Association for Advancement of Veterinary Research. Bareilly, UP (India), pp. 76-80 